\title{
Mary Hays, an Eighteenth-Century Woman Lexicographer at the Service of "the Female World"
}

\begin{abstract}
The English reformist writer Mary Hays published a compilation of women's biographies entitled Female Biography (1803), with the aim at providing other women with examples to emulate. She intended not only to convey her deepest convictions about women's capacities and abilities, but also to leave her own stylistic imprint on the text. This study seeks to analyse diverse entries of Hays's collection (Lady Dudleya North, Lady Damaris Masham, Margaret Roper, Aphra Behn, and Lady Rachel Russel) in order to elucidate her concerns as a data collector and biographer, and her techniques as a lexicographer, which are chiefly shaped by her concern about education and by her intended audience: women.
\end{abstract}

Keywords: Mary Hays; Female Biography; lexicography; women’s lives

\section{Mary Hays, leksikografinja iz osemnajstega stoletja v službi »ženskega sveta»}

\author{
POVZETEK
}

Angleška reformistka Mary Hays je 1. 1803 objavila zbirko biografij žensk z naslovom Female Biography, s katero je želela drugim ženskam predstaviti zglede, ki naj jim v svojem življenju sledijo. Poleg Haysinih trdnih prepričanj o sposobnostih in zmožnostih žensk besedilo razkriva tudi njene slogovne posebnosti. Pričujoča študija analizira posamezne vnose v Haysini zbirki (Lady Dudleya North, Lady Damaris Masham, Margaret Roper, Aphra Behn in Lady Rachel Russel) z namenom razjasnitve njenih vodil pri zbiranju biografskih podatkov in njenih leksikografskih tehnik, na katere sta zlasti vplivala njeno prepričanje o pomenu izobrazbe in njeno ciljno občinstvo: ženske.

Ključne besede: Mary Hays; Female Biography; leksikografija; življenja žensk 


\section{Mary Hays, an Eighteenth-century Woman Lexicographer at the Service of "the Female World"}

\section{Introduction}

In the Monthly Magazine of December 1798, a brief note announced that the English writer Mary Hays (1759-1843) had embarked on a "biographical work of great and lasting interest to the female world, to contain the lives of illustrious women, of all ages and nations" (qtd. in Luria Walker 2013, xii), which was finally published in six volumes in 1803, under the title of Female Biography; or, Memoirs of Illustrious and Celebrated Women of All Ages and Countries: Alphabetically Arranged. This demonstrates the extraordinary work undertaken by the author over at least five years, in which she not only consulted a great quantity of varied sources, but also endeavoured to leave her own imprint on the text she was creating. As the full title makes clear, Hays tried to include in her biographical dictionary celebrated women of disparate backgrounds and occupations. In the preface, she stated that she published accounts of the lives of illustrious women in order to provide her own sex with examples to be emulated (Hays 2013, 3). As a reformist writer, by means of these biographies Hays intended to convey her deepest convictions about women's capacities and abilities and to give visibility to women who had participated in the intellectual, cultural, and political realms of their time (Luria Walker 2006, 215-16).

Hays's opening words in Female Biography offer some meaningful testimonies on the issue of style. First, she quotes Peter Bayle's Dictionnaire historique et critique (1697) to declare that "to abridge with judgment, is of literary labours one of the most difficult" (2013, 8). Additionally, she admits a disdain for "mere compilation [...] aiming at a clear, correct, and even harmonious style" $(2013,8)$. As her "book is intended for women, and not for scholars," her purpose is "to collect and concentrate, in one interesting point of view, those engaging pictures, instructive narrations, and striking circumstances" $(2013,7)$. Did Mary Hays's biographies achieve these goals? The current study, while not comprehensive, seeks to provide an answer to this question by means of a preliminary approach to Hays's stylistic concerns as a data collector and biographer, and to her techniques as a lexicographer.

\section{Hays as a Vindicator of Women's Education}

Hays was born in a middle-class family of Rational Dissenters, and the death of her father, among other early misfortunes, was a determining factor in her life, as she gained first-hand of women taking on more responsibility in a patriarchal society. Later on, when she met Mary Wollstonecraft and other members of radical circles, she became acquainted with their revolutionary ideals, ${ }^{1}$ while she also received literary and emotional support to revive and continue her career as a writer. Hays thus enjoyed the positive influence of a cultural and intellectual milieu, in which women had the opportunity to participate in gatherings and debates and express their ideas. However, she quickly realized that women's role in the world of letters was that of outsiders (Luria Walker 2006, 1).

\footnotetext{
Hays and other writers of the 1790s, including William Godwin, Thomas Holcroft, Elizabeth Inchbald and Charlotte Smith, received the name of Jacobin novelists, as they focused on the positive consequences that the French Revolution could bring to English society. However, their intention was not revolutionary, as they simply called for a government guided by reason, and not by money or rank (Kelly 1976,8).
} 
Interestingly, Wollstonecraft acted as a mentor for Hays, the influence of the former's $A$ Vindication of the Right of Woman (1792) being especially strong on the latter, who consistently called for greater advancement and autonomy for women. Education was essential in this context, and Hays always demanded better instruction for women in her writings. Wollstonecraft and Hays were in turn admirers of Catharine Macaulay, a historian and activist, who shared with numerous women of the period a concern about women's education. ${ }^{2}$ Macaulay was well-known for her multivolume History of England (1754-1761); however, she also wrote an essay entitled Letters on Education, in 1790, in which she attacked the most relevant and widespread educational systems of that time, namely those proposed by Rousseau and Hume. According to these two men, the education that girls should receive was based on the association of women with lesser virtues, such as delicacy, smoothness, beauty and dependence (Frazer 2011, 608), which made them incapable of receiving the same education as boys. Macaulay, however, was in favour of an egalitarian education, for knowledge, in her opinion, was not determined by gender and thus she claimed that the assumed distinctions between men and women "do not in any manner proceed from sexual causes, but are entirely the effects of situation and education" $(1790,202)$.

In her collection of essays, Letters and Essays, Moral, and Miscellaneous (1793), Hays similarly expressed her indignation about certain common attitudes towards women, which not only damaged them, but also the whole of society: "By degrading the female character, and by repressing the wish for improvement, men have, with a narrow and temporary policy, been enemies, not only to their own happiness, but to their offspring" (1793, vii). Years later, in an article she published anonymously in 1797, "Improvements suggested in Female Education", Hays describes the terrible habit adopted by many families of her time, which consisted of bringing up their daughters just for "the precarious chance" of marriage $(1797,194)$. The consequence for these young women was victimization and helplessness. However, educated women would be able to practice diverse trades, including liberal arts, arithmetic and bookkeeping, which would permit them to support themselves and not to depend on men. To achieve this and defeat inequalities, Hays asks for government reforms and new policies, which should focus on individuals" "faculties and talents, without distinction of rank or sex" $(1797,195)$. Following the same path, Hays's two most well-known novels, Memoirs of Emma Courtney (1796) and The Victim of Prejudice (1799), can be described as compendia of all the injustices committed to the middle-class women of her time (Ty 1998, xvi), while in Female Biography she looked to women in the past in order to offer powerful examples to her readers, mostly women, so that they could fight prejudice and discrimination. Most of these examples were upper-class women, who had a better access to education, and thanks to the opportunity they enjoyed, were able to be and act as great women, and able to impact society (Luria Walker 2005, 255). Furthermore, Hays used some of these women's life stories- e.g. those of Lady Masham and Margaret Roper - to introduce her feminist viewpoints, particularly the issue of women's education, as will be discussed below.

In her Vindication of the Rights of Woman, written just after Macaulay's death, Wollstonecraft declared this about her: "The woman of the greatest abilities, undoubtedly, that this country has ever produced. -And yet this woman has been suffered to die without sufficient respect being paid to her memory", and she added that she was "an example of intellectual acquirements supposed to be incompatible with the weakness of her sex" $(1999,180)$. Hays was one of her first biographers and being herself very conscious of the prejudiced viewpoint with which some women writers were regarded and judged, stated about Macaulay: "A female historian, by its singularity, could not fail to excite attention: she seemed to have stepped out of the province of her sex; curiosity was sharpened, and malevolence provoked. The author was attacked by petty and personal scurrilities, to which it was believed her sex would render her vulnerable" (2014, V, 294). Indeed, Macaulay's radical political ideas and some personal circumstances affected her consideration and esteem among the public (Hill 1992, 117). 
Although women's education had been a controversial issue before, in the eighteenth century it became a particular point of contention, as the literary realm was more and more populated by female writers, and the rate of literacy among women was rising rapidly. Indeed, reading was not only more accessible to women but it also started to be considered a suitable activity for them. As Nancy Armstrong explains, during the eighteenth century a new model of woman emerged, confined to the domestic realm with the only task of supervising the household servants' work. and consequently such women had large amounts of leisure time $(1987,79)$. Many thus spent their spare time reading, although this new habit did eventually cause great anxiety, since it was more and more difficult to control what women read. Indeed, it was considered that women, due to their allegedly weaker disposition and vulnerability, were particularly susceptible to some materials and topics. Nevertheless, history was recommended as very beneficial for women's instruction, and among historical writings biographies of famous women were particularly popular. Moreover, intellectuals and scholars proposed this type of texts instead of fiction, since they gathered real examples and models for women readers to imitate (Pearson 1999, 51).

\section{Hays as a Data Collector and Lexicographer}

After the publication of Female Biography, both the structure and pattern of Hays's text were considered problematic, and thus a target of critical remarks by reviewers. Her selection of women subjects and the alphabetical arrangement of entries introduced a transgressive turn into the text, in that worthy and reprehensible women were set together. While this is a notable feature of the work, it was roundly criticised due to the negative effects that it might have on its intended readership (Luria Walker 2005, 330-33; Wood 1998, 117-18). The eighteenth century saw a huge number of compendia of this sort, and information in them was frequently presented in a logical, accessible manner. Indeed, most of Hays's contemporaries "favoured works in alphabetical order designed for rapid reference, rather than didactic works arranged thematically. Erudition was being displaced by efficient information storage and retrieval" (Headrick 2000, 172), so in adopting this arrangement she shows herself to be in sync with her times.

Similarly, more recent studies have expressed reservations as to the form of this compilation, considering it hack work, undertaken for mere financial gain (Kelly 1993, 246). Interestingly, Samuel Johnson's entry for "Grub Street" in A Dictionary of the English Language (1755) states that this well-known street in London was inhabited by literary hacks, mediocre and needy writers "of small histories, dictionaries, and temporary poems" (Encyclopaedia Britannica 2018), and includes dictionary compilers among the category of second-rate writers who worked chiefly for money. Taking into account the interests of both Hays and her publisher, the financial motivation for this work is indeed beyond doubt (Luria Walker 2006, 216; Luria Walker 2013, xii). Moreover, Hays's approach in the composition of her biographical dictionary took an inevitable course, and could hardly have been differently. Certainly, Isabel Rivers in an analysis of various eighteenth-century biographical dictionaries has explained the procedure for writers of such texts, which was based on borrowing; they "drew on earlier ones, or [...] took account of other dictionaries published in the meantime which commented on the earlier version. There would seem to be no end to the task of the modern historian hoping to disentangle the chain of borrowing, allusion and criticism" (2003, 137). This aspect is particularly evident in the case of Hays, who includes her sources at the end of most entries. And despite not citing every source, the enlightened spirit and empirical method in her compiling work is palpable (Capern 2005, 152). Moreover, at that time any borrowing could be justified in terms of a successful stylistic improvement, and indeed textual unity and seamlessness were the main features when 
evaluating literary works (Mazzeo 2007, 3-4). In this regard, Hays's text exemplifies such aims as refinement, together with the author's own opinions on her personal style, particularly regarding her target audience, women.

Susan Staves (2007) has raised the question of how eighteenth-century women writers got access to all the books they read, and considering the number of sources quoted by Hays, this question certainly arises in this case. Being a woman, and one of limited means, the option of purchasing so many books was beyond her. Moreover, women were excluded from almost all of those significant places where books could be read and consulted, including schools, universities and libraries, particularly if they were also dissenters, as with Hays. Nevertheless, the new paradigm established in the literary system of the time offered women new opportunities, and they were able to participate in this system as givers and receivers of books with "friends and colleagues engaged in a common project" (Staves 2007, 208). As an active member of various circles of like-minded writers and friends, Hays might have access to the private libraries of some of these (Spongberg 2014, 539), ${ }^{3}$ and particularly of those who were or had been engaged in similar projects. Staves mentions a further way in which women might have obtained books, one which again might have been exploited by Hays: some writers obtained books as a form of patronage by publishers, in that a supply of such books constituted the sort of material writers needed for the work they were doing for those very publishers (Staves 2007, 196). Thus Richard Philips, the publisher of Female Biography, might have supplied Hays with some of the biographical texts he had already printed; as a businessman interested in the increasingly popular genre of life-writing, this served his commercial purposes well (Luria Walker 2006, 216).

The title of the text suggests that Hays's primary purpose was very broad; although her own country remains a key element, given that approximately one third of the women recorded are British, and some of these women's biographies are among the most extensive ones. In terms of the form of the biographies, there is no uniform pattern, and the length of the entries varies considerably, from just a few sentences to essays of more than 100 pages, the latter being the case for both Elizabeth I and Mary Queen of Scots. However, most of the British women in Hays's text are not royal, and the most common length of the entries for these is far shorter. Some 94 British women are described (of the total of 300 entries for the whole work), most of these being noble and learned ladies, and a considerable number of them also writers (Lasa Álvarez 2014). There is one explanation of this: the sources used by Hays for the great majority of these entries. Clearly, if she wanted to produce a compilation of women's lives, her best approach would be to draw on existing texts of similar nature, which included principally "female worthies," that is, the kind of historical work which embraced those various female monarchs, warriors, saints, and savants distinguished by their rank, talent, piety, or otherwise noteworthy lives (Guest 2000, 49-69; Chernock 2013, 115-36; Hicks 2014, 18-33).

First, the crucial role of George Ballard's Memoirs of Several Ladies of Great Britain (1752) has to be recognized. This text is not only one of the most repeated sources in Hays's entries, but also the one which marked the emergence of a canon of worthy women, and "the key source for information about women writers in the Renaissance and seventeenth century for almost all subsequent biographical dictionaries including women writers, [... and $]$ for biographical notices in anthologies of women writers" (Guest 2000, 50, 78). Ballard was captivated by the

Hays had already enjoyed access to the private libraries of friends, such as Mrs Collier, when she was younger (Luria Walker 2006, 12). 
antiquarian method of recovering historical data and materials, but usually did not go on to make any detailed of analysis of the facts established (Chernock 2000, 119-20). As an antiquarian, his work lay mainly in collecting and gathering as much information as possible for each entry, including sources such as archival records, letters, wills, sermons, elegies, manuscripts, and even inscriptions on tombstones and monuments (Sweet 2004, xvi) ${ }^{4}$.

The anonymous Biographium Faemineum: The Female Worthies (1766) is also a source text for Hays. It reproduces many entries from Ballard's Memoirs, but in having a more inclusive objective, as set out in its title and preface, the collection includes foreign women and also some historical protagonists of scant virtue (1766, viii), such as Cleopatra and Aphra Behn. ${ }^{5}$ Finally, Thomas Gibbons's Memoirs of Eminently Pious Women (1777) should be also noted here. For Gibbons, a dissenting minister, religion and virtue were the salient criteria for his choice of subjects (1777, vii).

Evidently the use of these biographical materials, which incorporated the authors didactic purpose and ideological point of view, stressing such features as women's virtue and modesty, affected and sometimes shaped the way some of these women have subsequently been regarded. The women included in these authors' collections were celebrated for diverse reasons; however, their portrayals consistently included some sort of self-denying accomplishment, which was a prerogative of women's private roles as mothers, daughters and wives. They perhaps also influenced Mary Hays herself; it is thought that as a consequence of her use of earlier sources of this kind, she moved away from her previous radical and liberal views, to adopt a more conservative perspective and tone in her biographical compendium, more in accordance with the post-revolutionary atmosphere in Britain at the time (Kelly 1993, 234; Spongberg 2002, 117).

\section{Hays as a Biographer: Some Examples}

The biography of the Honourable Lady Dudleya North (1675-1712) is a good example of Hays's system of textual assembly and work. Lady Dudleya was member of a significant noble family actively involved in government and politics during the troubled second half of the seventeenth century in England. Despite this, she lived a mainly secluded life, devoting her entire life to study. However, thanks to her family's high position in society she was able to collect a large number of books, a pursuit which she shared with some of her relatives, such as Sir Roger North, one of her educated and cultivated uncles, a lawyer and biographer, and a member of the King's Counsel. The entry is just one page long, and at the end of it Hays offers a brief list of sources, which include "Ballard's British Ladies" and "Biographium Faemineum" (2014, 527). Lady Dudleya North's biography is reproduced with minor changes from Ballard's version, which is clearly also the source of the other text mentioned by Hays, Biographium Faemineum.

The process of summarising is clear and progressive, concluding with Hays's version, which, apart from being shorter, is, in my opinion, clearer, simpler and smoother than Ballard's original. Hays's biography is also reordered, following a more logical scheme. Thus Hays takes the section which explains that Lady Dudleya owned a notable collection of books and that it was donated to the parochial library after her death, and places this at the end of the entry, as these events occurred after the subject had died. It is, then, a simple but effective improvement in the presentation of information.

\footnotetext{
This collection also includes numerous exemplary women writers (Lasa Álvarez 2015).

The inclusion of such women in biographical collections was frequently accompanied by warning labels by the compilers (Booth 2004, 67), as Hays herself did in presenting Aphra Behn's life.
} 
In the case of a longer entry, such as Lady Damaris Masham (1658-1708), a philosopher of the late seventeenth and early eighteenth centuries, the same sources are used. Again, Hays and the anonymous author of the Biographium Faemineum both make use of Ballard's compilation. The difference in style is also clear in this case, since the anonymous compiler generally maintains the sentence structure of Ballard's text, while Hays tries to build a more flowing style. It is interesting to note in more detail the dissimilarities in the approaches of these two authors with respect to Ballard's text at the point where the latter reproduces Lady Masham's own words on education. Indeed, almost half of Ballard's entry concerns allusions to and quotations from one of her treatises: Occasional Thoughts in reference to a Virtuous Christian Life (1705), and particularly those aspects related to the education of both women and men. However, in the Biographium Faemineum the space assigned to it is no more than a short reference: "The principal design of which (education) is, to improve religion and virtue; and need it is so full of instruction, that, if carefully perused by both sexes, it could not fail of obtaining much of its desired end" (1766, 126), which might be seen as an invitation to read the book.

Mary Hays also summarises Ballard's text, but contrary to the author of Biographium Faemineum, and due to her personal interest in this matter, as previously examined, she draws on Masham's opinions to offer her readership another perspective on the necessity of women's education. As a friend and follower of Locke, Masham placed great importance on the civic and moral role of education in society, yet she focused her interest on women's education, and particularly on the role of cultivated mothers as educators of worthy citizens for an enlightened society (Hutton 2010, 74).6 After giving a general idea of Masham's opinion on the "neglected education of daughters, among persons of high rank, and the frivolity and dissipation in which they consume their lives," from the excerpts selected by Ballard, Hays chooses those parts in which gentlemen's mistaken ideas about education induce them to ridicule "a learned lady." This is particularly reprehensible, she argues, in that a learned lady is "capable of instructing her children, and of implanting in their minds just principles" (2014, 496-97).

There are several more entries in Hays's compilation based on the same sources, which illustrate the extent of her reliance on these two texts. Yet also very clear is her desire to infuse her text with her own style, and to emphasise those assumptions which she considers instrumental for the general aim of her biographical dictionary. Her personal interest here is seen in occasional additions to her core sources. A case in point is the biography of Margaret Roper (1505-1544), the cultivated daughter of Thomas More, Lord High Chancellor during the reign of Henry VIII. At the end of the entry Hays notes her usual sources, Ballard and Biographium Faemineum; however, the initial long paragraph of the entry is her own:

In favour of the liberal cultivation of the minds of women, it may be observed, that at no period of the English history does there appear to have been greater attention paid to the culture of the female mind, than during the age of Elizabeth; and at no time has there existed a greater number of amiable and respectable women. [...] Among women distinguished for their virtues and acquirements, in the $16^{\text {th }}$ century, the three daughters of Sir Thomas More hold an elevated rank (2014, 92-94).

On the following page, she adds an exclamation contrasting those favourable times for women's education to her less cultivated present-day gatherings: "What a charming picture, contrasted

When the notion of education was associated with women, this tended to imply domestic education, a task often undertaken by mothers, who by the end of the eighteenth century had acquired the role of the guardians of national knowledge (Davies 2014, 6-7). This issue was also emphasized by Mary Wollstonecraft (Kelly 1993, 243). 
with modern seminaries of vanity and dissipation!" $(2014,94)$. Curiously enough, Hays considers More's daughters as belonging to "the age of Elizabeth," while in Roper's biography several references to King Henry VIII, the reigning monarch at that time, can be found, particularly regarding the refusal of Roper's father to swear the oath of Supremacy and its fatal consequences. It is quite clear from her words in the entry that Hays was not overly fond of Henry VIII, describing him as "a capricious tyrant" $(2014,98) .^{7}$ As in the entry for Elizabeth I, various instances of the Queen's cultivated court and her inclination for study as part of the customs of the times are noted in Margaret Roper's entry, despite belonging to a previous historical moment.

In addition to using compilations of women's biographies, such as those mentioned above, Hays also drew on generalist collective biographies of the period (Spongberg 2014, 539), as her biography of the writer Aphra Behn (1640-1689) shows. This entry is somewhat contradictory, in that Hays initially calls her the English Sappho $(2013,385)$, and whereas she does recognize Behn's literary merits, her works are said not to be recommended, a somewhat perplexing and incongruent position in dealing with a writer. Indeed, Behn's works are "reprehensible for their licentiousness" and "do not serve the cause of virtue" (2013, 384-85). Hence, the sources assembled by Hays to construct Behn's portrait are of key interest here. At the end of her entry, just two are cited, "Biographia Britannica" and "Biographium Faemineum" $(2013,386)$. The former might refer to the biographical dictionary in six volumes, edited by William Oldys and published for the first time in England between 1747 and 1766. However, given the personal acquaintance between Mary Hays and Andrew Kippis, with both writers frequenting the same Dissenting circles (Spongberg 2010, 254), it is more than logical to think that she used the second edition of this compendium, which had been edited by Kippis.

A comparison of entries for Behn in both editions with Hays's own shows that she did indeed draw on the second edition, as we will see below. This new edition bears the same title, with the addition of the following information on the title-page: "The Second Edition, with Corrections, Enlargements, and the Addition of New Lives: By Andrew Kippis, D.D.F.R.S. and S.A. With the Assistance of the Rev. Joseph Towers, LL.D. and other Gentlemen” (1780, n.p.). It is in fact an incomplete edition of five volumes which appeared between 1778 and 1793. As already noted, Hays based her biographical dictionary on the guiding principles established by Bayle's in his influential work, as the editors of the Biographia Britannica also did. Indeed, Hays's close familiarity with Bayle is beyond doubt; Luria Walker pointed out that she was introduced to Bayle by Robert Robinson, another Dissenting scholar and minister (2013, xxiv). The second source for Behn's entry is Biographium Faemineum, as for other entries already discussed here.

An analysis of Hays's entry on Aphra Behn makes it clear that she extracted most of the data from the Biographia Britannica. Interestingly, the actual biography of Behn in this text is quite short, yet the scholarly footnotes with additional information and explanations occupy much more space $(1780,141-46) .{ }^{8}$ While the anonymous author of the Biographium Faeminum reproduced almost word for word the main text of the Biographia Britannica, Hays took both its components and rearranged them in her entry, thus offering a much more readable text. As a consequence of the use of this source, which combined biographical information and fictional excerpts, in Hays's text some material taken from Behn's well-known narrative Oroonoko; or, The Royal Slave (1686) is used as if it is an authentic and true account. Hays goes as far as mentioning a possible sexual relationship

An expression that Hays had used before in her biography of Queen Elizabeth I (2014, 73).

8 The editors of this biographical dictionary employed the same method used by Bayle in his text: the main text for the historical facts, and footnotes for discussion, commentaries and additional curious information (Rivers 2003, 138-39). 
between Behn and this prince. As happened in most of the early biographies of Behn, this affair is then refuted in Hays's text and described as a "calumny" (2013, 383). ${ }^{9}$ However, as Jane Spencer has explained, this denial "serves, of course, to draw attention to the titillating idea of a sexual relationship" (2000, 35). Similarly, Hays mentions "Some letters, addressed to a gentleman, whom she poetically calls Lycidas; are printed in her Memoirs: this attachment appears to have been not less tender and ardent than unfortunate" (2013, 383). The letters are interpreted biographically, when it is not entirely certain that they are even hers, yet again they contribute to introduce the reader to Behn as a passionate and desperate woman in love (Spencer 2000, 38).

Generally speaking, Behn's critical reception in the eighteenth century was negative, usually appearing in contrast to other women writers, such as Katherine Philips or Elizabeth Singer Rowe, who epitomised chastity and piousness (Todd 1998, 176). Hays, like her sources, adheres to this tendency and reiterates conservative comments about women's role in the public sphere (Wood 1998, 133-34). Nevertheless, it has also been noted that the mere inclusion of Behn in the compilation, together with the relative length of the entry, is significant and remarkable, given that this writer was conspicuously absent from most biographical collections of the period, more concerned as they were with presenting to their intended readers depictions of virtuous and pious women (Wood 1998, 132-33). Also, bearing in mind that Hays used the second edition of the Biographia Britannica as her main source to reconstruct Behn's life, her comments, while sometimes quite unfavourable, are much more benevolent and considerate than those expressed by one of the editors of the second edition of the Biographia Britannica, who used the final footnote to add new information about Behn, which is full of critical remarks on her works and character. Indeed, this latter editor, identified as $\mathrm{K}$ (perhaps Kippis himself), ${ }^{10}$ seems to congratulate himself on the fact that Behn's writings are "now little regarded, her novels excepted, which, we suppose, have still many readers among the unhappily too numerous a class of people who devour the trash of the circulating libraries" $(1780,146)$. Finally, he responds to a certain gentleman on the appropriateness of including in the Biographia Britannica such a character as Behn, saying that she had to be part of it, in that she was undeniably a celebrity in her times and her works very famous, "though, in her indelible disgrace, her talents were prostituted to licentious purposes" $(1780,146)$. Hays attempts to give a more tempered view of Behn's life and mentions "the manners of the times [...] and the contagion of the court" $(2013,385)$ as the causes for the censure of Behn's works, giving voice to the eighteenth-century construction of the writing in the Restoration period as decadent and salacious (Spencer 2000, 2). However, also, as Kelly has observed, Behn's biography might also serve to illustrate what is perhaps the most significant issue which Hays condemns in this compendium, "the historic corruption and trivialization of women in court culture" $(1993,239)$.

Finally, Hays also uses specific sources for individual entries, as is the case with Lady Rachel Russel (1636-1723), a rather long entry of 15 and a half pages, this reflecting her active and public life, and her longevity. The sources assembled by Hays here are "Hume's History of England", "Letters of Rachel, Lady Russell, from the MS in the Library at Wooburn Abbey" and "Memoirs of Pious Women" $(2014,346)$. That is, a recently published work of general history: David Hume's History of England (1754-1761), a specific text related exclusively to the subject of the entry: Letters of Lady Rachel Russell; from the Manuscript in the Library at Woburn Abbey (1773),

Hays takes the excerpt of Oroonoko from the corresponding footnote in Biographia Britannica, and she subsequently repeats the same procedure in the rest of the entry.

10 In the preface to the second volume of the Biographia Britannica, in which Behn's biography is included, some of the original writers are identified by an initial letter, but nothing is said about this editor whose signature is $\mathrm{K}$ (1780, viii). 
and the aforementioned Memoirs by Gibbons. Hays's approach to the use and organization of these sources is significantly different here. The main source is one text, which specifically deals with the woman in question, or better said, with her husband Lord William Russell. The text is an anonymous and favourable of his character, which was published as a preface to The Letters of Lady Russell, a collection that appeared in 1773, 50 years after her death. Hays, however, might have been first acquainted with her subject through Gibbons, one of the first authors to include Russell's biography in a compendium of this type. Although Lady Rachel was well known during her lifetime, and indeed was described by a contemporary as "One of the best of women", her life went practically unnoticed until her letters were published with the above-mentioned preface in 1773, after which her life enjoyed immediate popularity and was incorporated in women's biographical collections, as well as in other historical and literary texts, such as plays, and even in pictures (Schwoerer 1988, xxiv-xxvi; Culley 2014, 34-52).

The interest in Lady Russell's biography is a telling instance of what Paula Backscheider has noted about women and biography: "women in order to be worthy subjects of biographies, must marry into, fall into, or fashion a worthwhile role in life" (Backscheider 2001, 144). Lord Russell was Lady Rachel's second husband, a man who participated actively in English politics as a member of the Country Party, the forerunners of the Whigs. He allegedly took part in a conspiracy, the 1683 Rye House Plot, which sought to raise a rebellion by seizing King Charles II's guards, and thereby to kill him. On the $26^{\text {th }}$ of June, Russell was arrested and on the $13^{\text {th }}$ of July tried and found guilty of high treason. He was sentenced to death and executed on the $21^{\text {st }}$ of July 1683 .

Lady Russell's letters came to light just after the publication of John Dalrymple's Memoirs of Great Britain and Ireland. From the Dissolution of the Last Parliament of Charles II, until the Seabattle off La Hogue (1771-3). Dalrymple's work is the first history of late seventeenth-century Britain based on French sources, and it revealed that Lord Russell had plotted with members of the French court. This revelation damaged Russell's reputation and that same year the book including his wife's letters and the anonymous preface was published (Schwoerer 1988, xxiv; Culley 2014, 35). As mentioned above, most of the information in Hays's entry for Lady Russell comes from the Introduction to the Letters, at least in terms of the information on Lord Russell's involvement in the Rye House Plot, his arrest, trial, sentencing and execution; however, most of this information in turn derives from other sources quoted by the anonymous author of this Introduction. These include some of the best known historians and history books of the period: Bishop Burnet's History of His Own Time (1724), Paul de Rapin's L'Histoire d'Anglaterre (1724), and Thomas Birch's The Life of the Most Reverend Dr. John Tillotson (1725), among others. Additionally, on account of the main source employed, Hays's biography of Lady Russell is loaded with the ideology that pervades that text, vindicating Lord Russell and the Whigs and blaming the encroachments of the crown. For instance, Hays argues:

No one doubted the innocence of Russell respecting the charge of conspiring against the life of the king, which he solemnly denied with his dying breath. [...] his principal guilt had been his opposition in parliament to what he deemed unconstitutional measures, with his effort for the exclusion of the duke of York from the throne $(2014,336)$.

Although devoting almost half of Lady Russell's entry to the circumstances surrounding her husband's trial and execution, Hays takes the opportunity to introduce Lady Rachel within this account, given that she played an active role in her husband's trial and the events that followed. Hays describes how Lady Russell acted as an assistant to her husband, taking notes during the trial, at the express wish of Lord Russell himself, and the dramatic reaction of the assistants, 
who "melted in tears"; and later noting that "Lady Russell threw herself at the feet of the king, and pleaded with tears the merits and loyalty of her father, as an atonement" for the possible offences $(2014,335)$. The description of the couple's final parting is also extremely moving, in which she conducted herself with "heroic fortitude", and was said by her husband to have been a blessing to him $(2014,340)$. In fact, the attribute of fortitude has been a commonplace in the numerous biographical accounts of Lady Rachel, and it has been explained by her biographers as a combination of maternal and family duties with courage and dignity (Culley 2014, 38).

Lady Rachel survived her husband by 40 years, and thus the events after his death were taken not from the aforementioned Preface, but from her own letters plus annotations and appendixes added to these. Notable here is Lady Rachel's resilience on the death of one of her daughters, which appears in a footnote. Her youngest daughter, Catherine, died in childbirth, while the eldest one was also giving birth, and she had to cope with these tragic circumstances. In this case, Hays does not summarise or foreshorten the passage, with the clear purpose of conveying every dramatic feature of the story. Other significant episodes rendered by Hays include a dangerous incident involving a candle made with gunpowder, which Russell lit by mistake when reading in her bedroom, and information about her cataract operation.

\section{Conclusion}

The analysis presented above shows that Hays created a completely new biography for Lady Rachel, since Gibbons, (her other biographer), provided a much shorter entry in his collection, with fewer details, though he did incorporate some of her letters, unlike Hays. Whereas in other entries, Hays summarized the information she found in her habitual sources, in Lady Russell's case she had to make a more deliberate selection of exactly what she wanted to include in her entry. Thus this entry might be considered as coming closest to her portrait of an ideal woman: virtuous and pious, an affectionate daughter, wife and mother, who is able to endure life's trials with courage, values which are wholly in agreement with those of women typically portrayed in the "female worthies" kind of compilation, and with the type of historical characters that in Hays's opinion women readers seemed to enjoy the most:

Women, unsophisticated by the pedantry of the schools, read not for dry information, to load their memories with uninteresting facts, or to make a display of a vain erudition. A skeleton biography would afford to them but little gratification: they require pleasure to be mingled with instruction, lively images, the graces on sentiment, and the polish language (2013, I, iii-iv).

This brief analysis has shown that Mary Hays's labour as a lexicographer in Female Biography is not an example of mere "hack work," and that she tried to simplify and summarise her sources, as well as to select those aspects which might entertain and even shock her readers the most, while also being both educative and improving in nature. It thus seems clear that she always had her female readers in mind, having expressed in the Introduction to the work the assumption that women's "understandings are principally accessible through their affections" (2013, iv). In order to stir her readers' hearts, as has been examined in the article, Hays clearly exploits the most dramatic events in her subjects' lives, while in some other life-accounts, such as Behn's, she prefers to concentrate on salacious love affairs.

Furthermore, she proposed models of women "to excite a worthier emulation" (2013, v) in her audience, with the main purpose of providing instruction and combating prejudice against 
women. Hays and other women of her time, including Mary Wollstonecraft, Catharine Macaulay, Helen Maria Williams, Anna Laetitia Barbauld, Mary Robinson, Charlotte Smith, and Elizabeth Inchbald, were pejoratively called "unsex'd females" by T.J. Mathias and Reverend Polwhele, well-known representatives of conservative thought, due to their radical and revolutionary ideas. ${ }^{11}$ Hays in particular suffered strong personal criticism, in that she was, for instance, the target of Elizabeth Hamilton's satirical novel, Memoirs of Modern Philosophers (1800). More importantly, although in Female Biography Hays's lexicographic work was predominantly influenced by her sources, she was able to reveal quite often her personal feminist philosophy, which was rooted in the necessity of an egalitarian education for women and in forceful criticism of gender roles in the patriarchal English society of her time.

\section{Acknowledgements}

This article has been possible thanks to the support of the Research Group "Literatura e cultura inglesa moderna e contemporánea” (G000274), funded by the University of A Coruña, and the Research Network VINS “(Neo)Victorian Network in Spain” (MINECO, FFI2015-71025REDT).

\section{References}

Anon. 1766. Biographium Faemineum: The Female Worthies, Or, Memoirs of the Most Illustrious Ladies of All Ages and Nations Containing (exclusive of Foreigners) the Lives of Above Fourscore British Ladies. Collected from History, and the Most Approved Biographers, and Brought Down to the Present Time. London: Printed for S. Crowder, et al.

Armstrong, Nancy. 1987. Desire and Domestic Fiction. A Political History of the Novel. New York: Oxford University Press.

Backscheider, Paula R. 2001. Reflections on Biography. Oxford: Oxford University Press.

Ballard, George. 1985 [1752]. Memoirs of Several Ladies of Great Britain, Who Have Been Celebrated for Their Writings or Skill in the Learned Languages, Arts and Sciences, edited by Ruth Perry. Detroit: Wayne State University Press.

Booth, Alison. 2004. How to Make It as a Woman. Collective Biographical History from Victoria to the Present. Chicago: The University of Chicago Press.

Capern, Amanda L. 2005. "Enlightenment." In Companion to Women's Historical Writing, edited by Mary Spongberg, Barbara Caine, and Ann Curthoys, 152-60. Basingstoke: Palgrave.

Chernock, Arianne. 2013. "Gender and the Politics of Exceptionalism in the Writing of British Women's History.” In Making Women's Histories: Beyond National Perspectives, edited by Pamela S. Nadell and Kate Haulman, 115-36. New York: New York University Press.

Culley, Amy. 2014. "Reading the Past. Women Writers and the Afterlives of Lady Rachel Russell.” In Historical Writing in Britain 1688-1830. Visions of History, edited by Ben Dew and Fiona Price, 34-52. Basingstoke: Palgrave.

11 Polwhele published anonymously in 1798 a poem entitled The unsex'd females: a poem, addressed to the author of the Pursuits of literature. He referred to Hays as follows: "flippant HAYS assum'd a cynic leer", and in a footnote he further explained that although this writer is little known, "she is evidently a Wollstonecraftian" (qtd. in Luria Walker 2005, 249), using this term with a derogatory meaning. Polwhele was inspired by T.J. Mathias, to whom he addressed his text. Indeed, Mathias in The Pursuits of Literature (1798) had written about "our unsex'd female writers (who) now instruct, or confuse, us and themselves, in the labyrinth of politics, or turn us wild with Gallic frenzy" (qtd. in Pascoe 2004, 213). 
Davies, Rebecca. 2014. Written Maternal Authority and Eighteenth-Century Education in Britain. Educating by the Book. Farnham: Ashgate.

Encyclopaedia Britannica Online. 2018. “Grub Street. Literary Hacks.” https://www.britannica.com/topic/ Grub-Street.

Frazer, Elizabeth. 2011. "Mary Wollstonecraft and Catharine Macaulay on Education." Oxford Review on Education 37/5: 603-17. https://doi.org/10.1080/03054985.2011.625165.

Guest, Harriet. 2000. Small Change. Women, Learning, Patriotism, 1750-1810. Chicago: The University of Chicago Press.

Gibbons, Thomas. 1777. Memoirs of Eminently Pious Women Who Were Ornaments to Their Sex, Blessings to Their Families, and Edifying Examples to the Church and World. London: Buckland.

Hays, Mary. 1793. Letters and Essays, Moral, and Miscellaneous. London: T. Knott.

—. 1797. "Improvements Suggested in Female Education." The Monthly Magazine and British Register 3: 193-95.

-. 2013 [1803]. Female Biography; or, Memoirs of Illustrious and Celebrated Women, of All Ages and Countries. Alphabetically Arranged, edited by Gina Luria Walker. Vols. I-III. London: Pickering \& Chatto.

-. 2014 [1803]. Female Biography; or, Memoirs of Illustrious and Celebrated Women, of All Ages and Countries. Alphabetically Arranged, edited by Gina Luria Walker. Vols. IV-VI. London: Pickering \& Chatto.

Headrick, Daniel R. 2000. When Information Came to Age. Technologies of Knowledge in the Age of Reason and Revolution, 1700-1850. Oxford: Oxford University Press.

Hicks, Philip. 2014. "Female Worthies and the Genres of Women's History." In Historical Writing in Britain, 1688-1830. Visions of History, edited by Ben Dew and Fiona Price, 18-33. Basingstoke: Palgrave.

Hill, Bridget. 1992. The Republican Virago. The Life and Times of Catharine Macaulay, Historian. Oxford: Clarendon Press.

Hutton, Sarah. 2010. "Masham, Damaris (née Cudworth)." In The Continuum Companion to Locke, edited by S.-J. Savonis-Wroth, Paul Schuurman and Jonathan Walmsley, 72-76. London: Continuum.

Kelly, Gary. 1976. The English Jacobin Novel 1780-1805. Oxford: Clarendon Press.

—. 1993. Women, Writing and the Revolution 1790-1827. Oxford: Oxford University Press.

Lasa Álvarez, Begoña. 2014. "The Discourse in Compilations of Women's Biographies in the Eighteenth Century: Constructing a Portrait of the Female Writer as a Model of Behaviour." Ateneum Philological Forum 1/2: 25-40.

—. 2015. "Constructing a Portrait of the Early-Modern Woman Writer for Eighteenth-Century Female Readers: George Ballard's Memoirs of Several Ladies of Great Britain (1752)." Sederi-Yearbook of the Spanish and Portuguese Society for English Renaissance Studies 25: 105-27. http://www.redalyc.org/articulo. oa?id=333543052006.

Luria Walker, Gina, ed. 2005. The Idea of Being Free. A Mary Hays Reader. Peterborough: Broadview.

-. 2006. Mary Hays (1759-1843). The Growth of a Woman's Mind. Aldershot: Ashgate.

—. 2013. "General Introduction". In Female Biography; or, Memoirs of Illustrious and Celebrated Women, of All Ages and Countries. Alphabetically Arranged. Vol. I, edited by Gina Luria Walker, xi-xxx. London: Pickering \& Chatto.

Macaulay, Catharine. 1994 [1790]. Letters on Education. Facsimile edition. Oxford: Woodstock Books.

Mazzeo, Tilar J. 2007. Plagiarism and Literary Property in the Romantic Period. Philadelphia, PE: University of Pennsylvania Press. 
Pascoe, Judith. 2004. “'Unsex'd females': Barbauld, Robinson, and Smith.” In The Cambridge Companion to English Literature, 1740-1830, edited by Thomas Keymer and Jon Mee, 211-26. Cambridge: Cambridge University Press.

Pearson, Jacqueline. 1999. Women's Reading in Britain 1750-1835. Cambridge: Cambridge University Press.

Rivers, Isabel. 2003. "Biographical Dictionaries and their Uses from Bayle to Chalmers." In Books and their Readers in Eighteenth-Century England: New Essays, edited by Isabel Rivers, 135-69. London: Continuum.

Schwoerer, Lois G. 1988. Lady Rachel Russell "One of the Best of Women." Baltimore: Johns Hopkins University Press.

Spencer, Jane. 2000. Aphra Behn's Afterlife. Oxford: Oxford University Press.

Spongberg, Mary. 2002. Writing Women's History since the Renaissance. Basingstoke: Palgrave.

—. 2010. "Mary Hays and Mary Wollstonecraft and the Evolution of Dissenting Feminism." Enlightenment and Dissent 26: 230-58.

—. 2014. "The Sources of Female Biography". In Female Biography; or, Memoirs of Illustrious and Celebrated Women, of All Ages and Countries. Alphabetically Arranged. Vol. VI, edited by Gina Luria Walker, 535-44. London: Pickering \& Chatto.

Staves, Susan. 2007. “'Books without Which I Cannot Write:' How Did Eighteenth-Century Women Writers Get the Books They Read?" In Women and Material Culture, 1660-1830, edited by Jannie Batchelor and Cora Kaplan, 192-211. Basingstoke: Palgrave.

Sweet, Rosemary. 2004. Antiquaries: The Discovery of the Past in Eighteenth-Century Britain. London \& New York: Palgrave.

Todd, Janet. 1998. The Critical Fortunes of Aphra Behn. Columbia SC: Camden House.

Ty, Eleanor. 1998. Introduction to The Victim of Prejudice, by Mary Hays, $2^{\text {nd }}$ ed., edited by Eleanor Ty, ixxxxix. Peterborough, Ontario: Broadview.

VV. AA. 1780. Biographia Britannica: Or, The Lives of the Most Eminent Persons Who Have Flourished in Great Britain and Ireland, from the Earliest Ages, down to the Present Times, vol. II. London: W. and A. Strahan.

Wollstonecraft, Mary. 1999. A Vindication of the Rights of Woman. A Vindication of the Rights of Men, edited by Janet Todd. Oxford: Oxford University Press.

Wood, Jeanne. 1998. “'Alphabetically Arranged': Mary Hays's Female Biography and the Biographical Dictionary." Genre 31: 117-42. 